\title{
Loss of MSH6 and PMS2 immunohistochemical staining in tumour tissue of two individuals with a germline PMS2 mutation
}

\author{
E Edwards ${ }^{1 *}$, M Bowman $^{1}$, M Walsh $^{2}$, J Kirk ${ }^{1}$ \\ From Familial Aspects of Cancer 2011 Research and Practice: A combined meeting of kConFab, Australian \\ Breast Cancer Family Study, Australian Colorectal Cancer Family Study, Australian Ovarian Cancer Study, \\ Family Cancer Clinics of Australia and New Zealand and kConFab \\ Kingscliff, Australia. 23-26 August 2011
}

Lynch syndrome is an autosomal dominant cancer predisposition syndrome which is caused by a germline mutation in one of four genes, MLH1, MSH2, MSH6 or PMS2. Individuals with a germline mutation in one of these genes are at increased lifetime risk of colon, endometrial, ovarian, small intestine, renal pelvis and ureter. Less commonly patients may develop biliary tract cancers, gastric and pancreatic cancers, brain tumours, sebaceous adenomas, carcinomas and skin keratoacanthomas.

Immunohistochemical staining for the above four mismatch repair (MMR) proteins is routinely performed for individuals with bowel cancer or a related cancer who are suspected of having Lynch syndrome. This helps target genetic testing to the correct mismatch repair gene. The genes involved in Lynch syndrome work together in a DNA repair complex. The MMR proteins form a heterodimer with MLH1 partnering PMS1, PMS2 or MLH3 and MSH2 partnering MSH3 or MSH6. This means that a mutation in MLH1 leads to loss of staining of both MLH1 and PMS2, while a mutation in MSH2 leads to loss of staining of both MSH2 and MSH6. The same is not true however, for mutations in either PMS2 or MSH6, where only the single protein made by these genes is not expressed in the tumour.

However, the pattern of staining using immunohistochemistry is sometimes more complex due to coding microsatellites within the MSH6 gene. We present two unrelated cases with a germline PMS2 mutation which

'Westmead Familial Cancer Service, Westmead Hospital, Australia Full list of author information is available at the end of the article had loss of both MSH6 and PMS2, but normal MLH1 and $\mathrm{MSH} 2$ on immunohistochemical staining.

\section{Author details}

${ }^{1}$ Westmead Familial Cancer Service, Westmead Hospital, Australia. ${ }^{2}$ Familial Cancer Laboratory, Queensland Institute of Medical Research, Australia.

Published: 12 April 2012

doi:10.1186/1897-4287-10-S2-A76

Cite this article as: Edwards et al:: Loss of MSH6 and PMS2 immunohistochemical staining in tumour tissue of two individuals with a germline PMS2 mutation. Hereditary Cancer in Clinical Practice 201210 (Suppl 2):A76.

Submit your next manuscript to BioMed Central and take full advantage of:

- Convenient online submission

- Thorough peer review

- No space constraints or color figure charges

- Immediate publication on acceptance

- Inclusion in PubMed, CAS, Scopus and Google Scholar

- Research which is freely available for redistribution 